\title{
„Základní kameny“ bretonského regionalismu. Jeho vznik a vývoj do roku $1914^{\star}$
}

\author{
MARTINA REITEROVÁ**
}

Cornerstones of Breton Regionalism. Its Emergence and Development until 1914

\begin{abstract}
This study deals with the circumstances of the emergence and development of the regionalist movement in Brittany before 1914. It focuses on the ancient and recent causes of breton regionalism and tries to briefly characterize it. We devote the first part to the older history of Brittany from which the Breton regionalists adopted the main arguments for their movement. The second part of the study describes the processes in the 19th century that led directly to the foundation of Union régionaliste bretonne in 1898 considered to be the beginning of the Breton regionalist activities. The study provides an introduction to the topic and offers an explanation of the growth and later on the failure of the Breton regionalism. The study's aim is to introduce this topic to the Czech scholars and to contribute to the study of nationalism and regionalism in the Czech historiography.
\end{abstract}

Keywords: regionalism; Brittany; 19th century; Third Republic; France

DOI: $10.14712 / 23363525.2018 .52$

\section{Úvod}

Bretonské regionalistické hnutí se objevuje na konci 19. století v době upevňování a centralizace moci francouzského státu v období Třetí republiky. Zařazuje se do myšlenkového proudu, který nazýváme bretonské hnutí, tzv. Emsav. ${ }^{1}$ Velice obecně lze toto hnutí definovat jako různé iniciativy a organizace stavící se proti kulturní, ekonomické, sociální a administrativní podřízenosti Bretonců ve Francii [Croix - Cassard - Le Quéau 2008: 520]. Většina historických studií bretonské hnutí rozděluje na tři fáze: první, trvající od 19. století do počátku první světové války, druhou, která končí německou okupací, a poslední fázi počínající těsně po druhé světové válce trvající až dodnes [Cadiou 2013: 8].

Tento článek představuje uvedení do problematiky bretonského regionalismu a poukazuje především na př́ičiny vzniku tohoto jevu a vývoj v jeho počátcích. Nelze pochopitelně předpokládat hlubší znalost kontextu vzniku bretonského hnutí u českého, ba i odborného publika. V české historiografii jsou k tomuto tématu k nalezení spíše jen zmínky, studie

\footnotetext{
* Tento článek byl napsán v návaznosti na diplomovou práci autorky s názvem L'auto-représentation des Bretons dans le discours régionaliste entre la fin du XIXe siècle et la Première Guerre mondiale, obhájenou dne 21. 6. 2016 na Ecole des hautes études en sciences sociales, Paříž.

** Mgr. Martina Reiterová, Seminář obecných a komparativních dějin, Filozofická fakulta, Univerzita Karlova, nám. Jana Palacha 2, 11638 Praha 1. E-mail: mareiterova@gmail.com.

1 Emsav je bretonské slovo pro „obrozeni“ či „povstáni“ a jeho význam je obecný, používaný pro označení celého bretonského hnutí, at se jedná o regionalistické, autonomní snahy, či snahy o úplnou autonomii Bretaně [Cornette 2008b: 453].
} 
téměř žádné. ${ }^{2}$ Geograficky je toto téma poměrně vzdáleno a př́mé vazby exkluzivního charakteru bretonského a českého obrozeneckého hnutí nebyly dosud objeveny. Zájemce o toto téma je tedy nucen sáhnout po cizojazyčné, v České republice mnohdy nedostupné literatuře. Přitom je nepopiratelné, že toto téma má v české historiografii komparativní potenciál. Práce má tedy za úkol zpř́istupnit téma bretonského regionalismu v českém prostředí a klade si za cíl představit odbornému publiku autorčin výzkum sebereprezentace a stereotypizace Bretaně počátku 20. století. Jak bylo již naznačeno, budeme se na následujících stranách ptát především po příčinách vzniku bretonského regionalismu a vývoji v počátcích hnutí. Časově bude studie ukončena rokem 1914, tedy počátkem první světové války, která v dějinách bretonského hnutí představuje výraznou transformaci a změnu diskurzu. Studie je založena na původním výzkumu regionalistických bulletinů a zahraniční odborné literatuře.

V první řadě je potřeba definovat základní pojmy. Regionalismus a region jsou jen těžko jednotně definovatelnými pojmy. Jejich definice se liší nejen $\mathrm{v}$ závislosti na vědecké disciplíně, ale také podle kontextů národních. Pokusíme se tak nicméně ve zkratce učinit pro účely tématu tohoto článku. Zajímat nás tedy bude hlavně vnímání regionu a regionalismu ve francouzském prostředí v 19. a na počátku 20. století.

Ve slovníku pojmů Grand dictionnaire universel du XIXe siècle od Pierra Laroussea z roku 1875 je region popsán jako „kraj, rozsáhlé území, jehož rozloha je určená jednotkou její správy nebo zvykovými vztahy či původem jeho obyvatel“. ${ }^{3}$ Označení „kraj”, které je zde chápáno jako synonymum slova "region“, poukazuje na jeho podřízení vůči vyššímu územnímu celku, národnímu státu. Tento vztah podřízenosti je pro vnímání termínů region a regionalismus v našem kontextu zásadní. Samotné slovo „regionalismus“ se objevuje v 19. století ve smyslu nedokončené centralizace, např́ílad v souvislosti s roztř́íštěností italského území v této době. $\mathrm{V}$ tomto smyslu také termín přechází do kontextu proticentralistických hnutí, která požadují určitou formu autonomie na regionální úrovni. Přitom si regionalismus zároveň zachovává původní význam podřízení se [Williams 1983: 264, 265]. Před rokem 1900 se slovo regionalismus objevuje spíše jen jako technický termín, teprve poté přechází i do všeobecného diskurzu [Flory 1966: 2, 3]. Obzvláště zajímavý je pro nás fakt, že slovo régionaliste („regionalistický") bylo poprvé ve všeobecném diskurzu ve Francii použito pro název Union régionaliste bretonne („Bretonská regionalistická unie“), založené roku 1898, jež je dokonce považována za první regionalistickou bretonskou organizaci. Teprve poté slovo régionaliste přešlo do názvu Fédération régionaliste française („Francouzská regionalistická federace“) [Thiesse 1992: 26].

Pro naplnění výše uvedených cílů je zde předkládaný článek rozdělen na dva hlavní oddíly a závěr. $V$ první, bezprostředně následující ćásti se zaměříme na historický vývoj Bretaně, který vedl k vytvoření základů pro místní regionalistické hnutí. Část druhá naváže vznikem hnutí jako takového v 19. století a jeho vývojem až do roku 1914. Závěr práce

2 V české moderní historiografii se bretonskému hnutí okrajově věnovaly studie zabývající se evropskými nacionálními a regionalistickými hnutími obecně, jako např. Hroch, Miroslav [1999]. V národním zájmu. Praha: Nakladatelství Lidové noviny. Ze starších studií, které se zaměřovaly přímo na bretonský regionalismus, lze zmínit články Richarda Weinera z Lidových novin z let 1921, 1929 a 1932 (převzato z Potopené zrcadlo. Legen$d y$, pověsti a pověry z Bretaně [2005]. Praha: ARGO.)

3 „Contrée, vaste pays dont l'étendue est déterminée par l'unité de gouvernement ou quelques relations de moeurs ou d'origine chez les peuples qui l'habitent" [Larousse 1875: 853]. 
bude sloužit především ke shrnutí hlavních argumentů textu a stručnému náhledu do moderních dějin bretonského regionalismu ve 20 . století.

\section{Původ a inspirace}

Pro pochopení původu bretonského regionalismu je potřeba ohlédnout se za některými z dávnějších aspektů dějin Bretaně, na jejichž základě bylo toto hnutí založeno. Zároveň také na následujících řádcích shrneme dějiny bretonského teritoria od starověku až po období Francouzské revoluce. První z aspektů, který zde zdůrazníme, budou „keltské“ dějiny a původ bretonského jazyka, jenž představuje jeden ze základních kamenů bretonského regionalismu. Dále se zaměříme na období, kdy byla Bretaň nezávislým svrchovaným územím, na něž bretonští regionalisté také s radostí poukazovali při prosazování svých požadavků. A nakonec rozebereme slavné bretonské revolty, které regionalisty při jejich počínání značně inspirovaly.

Dle archeologických poznatků bylo území Armoriky, jak byla Bretaň dřive nazývána, obýváno tzv. Kelty v období od 3. století před Kristem až do její romanizace na počátku 3. století po Kristu. Náboženství místního obyvatelstva se podobalo jiným polyteismům, ovšem u tohoto typu se kněžími mohli stát muži i ženy. Ti nejvýše postavení z nich se nazývali druidové. Druidové představovali velmi váženou vrstvu obyvatelstva kmene, která si ústně předávala básně na různá témata jako náboženství, právo, magie, dějiny a astronomie [Haywood - Cunliffe - Stevanovitch 2002: 26-33, 64, 65]. K poklesu jejich významu došlo během 1. století před Kristem [Cadiou 2013: 122]. Byly to právě armorické elity, které jako první z obyvatel tohoto poloostrova s radostí převzali do užívání rímské zvyky, náboženství i jazyk - latinu smíchanou s místním „keltským“ jazykem. Běžné venkovské obyvatelstvo hovořilo keltským jazykem až do pádu římského impéria [Cornette 2008a: 101]. Bretonci se do Armoriky dostávají až v polovině 5. století migrací z Británie, z oblastí dnešního Walesu, Cornwallu a Devonu. Historici se domnívají, že tito migranti na evropský kontinent utekli před skotskými nájezdníky [Le Roy Ladurie 2001: 71-72]. Zdá se být pravděpodobné, že je původní galo-ř́mské obyvatelstvo velmi brzy přijalo a došlo k jejich promíšení, i kvůli dobyvatelským snahám Franků. Ty vyústily roku 510 v podepsání mírové smlouvy mezi franckým králem Chlodvíkem I. a Bretonci, díky níž se Frankové vyhnuli složitému dobývání bretonského území. Jednalo se o kompromis výhodný pro obě strany. Bretonští králové se ve smlouvě podřídili Frankủm a zavázali se, že budou užívat pouze titulu vévoda. Na oplátku získali území, jehož východní hranice se táhla od Mont-SaintMichel až k ústí řeky Vilaine. Navíc tím, že se Bretonci v dohodě nezavázali platit tribut, uchránili si vůči Franckému království svou nezávislost. Tato úmluva ve svém důsledku usnadnila a urychlila další migrační vlny, které do Armoriky z britských ostrovů dorazily [Cornette 2008a: 116].

Bretonci, kteří se dostali do Armoriky z Britských ostrovů, si kvůli své relativní autonomii ve srovnání s ř́mskou Gálií ponechali některé ze svých zvykủ, včetně původního keltského jazyka. Proto někteř́ autoři hovoří o „rekeltizaci“ Armoriky [Markale 1985: 18-19, 25]. Jejich ostrovní keltský jazyk se poté smíchal s původním kontinentálním, a tak se vytvořil jazyk bretonský. Část obyvatel Bretaně si ponechala svou vulgární latinu, která se později př̀eměnila v jazyk gallo [Cornette 2008a: 122]. Takto tedy vzniklo tradiční jazykové rozdělení Bretaně, kdy se v tzv. Horní Bretani na východě poloostrova mluvilo jazykem 
gallo (románský jazyk podobný francouzštině) a v západní polovině, tzv. Dolní Bretani, bretonsky (keltský jazyk nerománského původu) [Broudic 1995: 83-89]. Migranti z ostrovů také mimo jiné do Armoriky přivezli svůj vlastní správní systém, klanové uspořádání pod vedením aristokracie a také náboženský život organizovaný nikoliv okolo biskupství, ale klášterů a opatů, tak jak to známe např́íklad i ze středověkého Irska [Markale 1985: 20, 36]. Tímto způsobem a bez známek podřízení Francouzskému království bretonský systém správy fungoval až do konce tisíciletí [Le Roy Ladurie 2001: 72-73]. V této době dokonce vzniklo i Bretonské království pod vedením legendárního krále Nominoëho, ačkoliv neexistovalo dlouho, pouze od roku 845 do počátku 10. století [Cornette 2008a: 175].

Nyní se dostáváme k tématu historické nezávislosti Bretaně, kterou bretonští regionalisté využívali jako jednoho $\mathrm{z}$ hlavních argumentů. Tento typ úvah je nejvíce využívaným ve většině národních hnutí. Vědomí a pamět středověkého státu představoval významný nástroj k dosažení autonomních cílů. ${ }^{4}$ Otázka tedy zní, jakým způsobem se Bretaň nakonec dostala do francouzského područí.

Proces rozbití bretonského individualismu počal invazí Normanů na konci prvního tisíciletí, která zničila místní křestanský náboženský systém „keltského“ charakteru popsaný výše. $\mathrm{V}$ důsledku toho to tedy byli představitelé rímskokatolické latinské církve původem z Francie, kteř́ se ujali náboženské správy v bretonském vévodství. Francouzský vliv byl postupem času stále silnější, až nakonec roku 1230 bretonský vévoda vzdal hold francouzskému králi tím, že jej doprovodil na kř́žovou výpravu [Le Roy Ladurie 2001: 73]. V průběhu Stoleté války rovněž nemohla Bretaň zůstat nestrannou, už jen kvưli své geografické poloze. Proto se vévoda Jan III. Dobrý zapojil do bojů ve Flandrech, a to na francouzské straně. Svou roli v tom hrál také vazalský vztah Jana $\mathrm{k}$ francouzské koruně. S jeho smrtí roku 1341 Bretaň zachvátily války o dědictví a bretonské území se v této době proměnilo také v bitevní pole Války stoleté. Oba pretendenti se totiž postavili na opačné strany konfliktu, jeden na francouzskou, druhý na anglickou. Nakonec to byl Jan z Monfortu, který se za podpory Angličanů stal novým vévodou Bretaně [Cornette 2008a: 255, $256,285]$. Tyto události vedly k vládě pěti po sobě jdoucích nezávislých bretonských vévodů, i přes silné napětí společnosti zpưsobené touto „občanskou“ válkou. Zvláště období vlád Jana IV. a jeho syna Jana V. (1365-1442) je považováno z hlediska nezávislosti Bretaně na Francii za nejvíce úspěšné [Cadiou 2013: 18].

Ačkoliv byl tímto obdobím vliv Francouzského království v Bretani oslaben, obnovil se spolu s Ludvíkem XI. a Karlem VIII. na konci 15. století, aby vévodství zabránili stát se anglickým spojencem [Le Roy Ladurie 2001: 76]. Karel VIII. využil situace kolem smrti vévody Františka II. a roku 1488 vtrhl se svou armádou na bretonský poloostrov. Dva roky po vypuknutí války mezi Francií a Bretaní nakonec Anna, vévodkyně bretonská, souhlasila se sňatkem s Karlem VIII., a tím se stala francouzskou královnou. Anně se ještě podařilo udržet suverenitu své rodné země, ale její dcera Klaudie, nová bretonská vévodkyně, již svému muži, francouzskému králi Františku I., podlehla a ten přidružil Bretaň zcela k francouzskému teritoriu roku 1532 [Cornette 2008a: 384-418]. Toto spojení nicméně pro Bretaň stále znamenalo jistou vnitřní autonomii v rámci království, zvláštní statut a jistá práva a svobody. Bretaň si např́ílad ponechala své nezávislé instituce, jako zákonodárné Stavy a také parlament, jenž představoval nezávislou moc soudní. Dále si Bretaň mohla

4 Více Hroch, Miroslav [1999]. V národním zájmu. Praha: Nakladatelství Lidové noviny. 
ponechat rozhodování ve věcích fiskálních, kdy všechny změny musely schválit i bretonské stavy a vybrané daně mohly být použity pouze pro bretonské účely. V oblasti soudní zůstal systém téměř stejný a žádný obyvatel Bretaně nemohl být předvolán mimo území provincie. A nakonec, beneficia byla předurčena pouze Bretoncům a místní vojáci nemohli být povoláni za hranice své provincie. Naopak francouzský král získal právo jmenovat funkcionáře a úředníky. Navíc byl v Bretani zřízen nový post představitele a ochránce centrální moci, tzv. „Generál místodržící krále pro Bretaň“ (Gouverneur-Lieutenant Général du Roi pour la Bretagne), který měl udržovat veřejný pořádek a také předsedat bretonskému parlamentu [Denis 1992: 12-13].

Spojení Bretaně s Francií mělo své odpůrce již od počátku. Slavné bretonské revolty proti francouzské nadvládě značně poznamenaly regionalisty 19. století. Zaměříme se nyní na vývoj a dějiny revolt, tohoto významného zdroje inspirace pro bretonský regionalismus.

Období, jež započalo připojením Bretaně k francouzskému teritoriu, představuje zlatý věk dějin poloostrova. Vyznačuje se především značnou hospodářskou konjunkturou, rozmachem námořních aktivit, a $\mathrm{v}$ důsledku toho př́sunem velkého množství peněž do provincie. Obchod mezi bretonskými přístavy, Novým světem a Středozemím se nebývale rozšíril a těžila z toho především přístavní města jako Saint-Malo a Nantes [Le Roy Ladurie 2001: 76-79]. Tento významný hospodářský rozvoj regionu byl ovšem pouze dočasný a př̀rušila ho v roce 1675 slavná Révolte des Bonnets rouges, neboli „Vzpoura červených čapek“. Ř́kalo se jí také „Vzpoura kolkovaného papíru“, poukazující na svou příčinu. Ministr financí Colbert se kvưli francouzsko-holandské válce rozhodl zvýšit daně na koupi kolkovaného papíru, který byl potřeba k jakémukoliv soudnímu úkonu, a také na nákup všech výrobků z cínu. Zároveň s tím zavedl královský monopol na prodej tabáku. Tato opatření ukazují, proč bylo povstání tak významné a početné. Dotkla se totiž různých sociálních vrstev, a proto se vzpoury zúčastnili nejen vesničané, ale i měštané. Nepokoje nejprve propukly v bretonských městech a poté se rozšírily i do Dolní Bretaně a rurálních oblastí, kde na sebe vzala podobu skutečných protipanských povstání. Povstalci nosili červené nebo modré čapky, rabovali a napadali hrady a zabíjeli příslušníky šlechty. I přes svůj zápal byla revolta nakonec ukončena smrtí jejího vưdce, Sébastiena Le Balpa [Cornette 2008a: 605-613]. Tresty padly jen na obyvatele vybraných měst a vsí (hlavně Rennes a některé vesnice z Dolní Bretaně) a byly exemplárního charakteru, tudíž přísné (popravy, zatčení, služba na galérách, atd.). Žádný z požadavků vzbouřeného lidu nebyl prosazen [Cornette 2008a: 621; Cadiou 2013: 45].

Od konce 17. století se Bretaň stala územím, odkud by francouzská armáda s největší pravděpodobností vedla svůj útok proti nepřátelské Anglii. $Z$ tohoto důvodu poloostrov trpěl neustálou přítomností francouzských vojáků. Zároveň zde samozřejmě byli i proto, aby udržovali pořádek a poslušnost Bretonců po proběhlé revoltě. $\mathrm{V}$ důsledku toho byla v Bretani této doby citelná rostoucí centralizace [Le Roy Ladurie 2001: 83]. Nicméně, proti těmto pořádkům a zaváděním různých opatření ${ }^{5}$ se v Bretani nevytvořila žádná opozice, zdá se tedy, že se provincie v této době zcela podrobila centrální vládě v čele s francouzským králem.

51689 - jmenování nového správce; 1692-1715 - založení množství nových úřadů; 1695 - zavedení nových daní z hlavy, aj. 
Oproti tomu období od smrtí Ludvíka XIV. až do Revoluce se naopak vyznačuje pokusy bretonské nobility o koncentraci moci ve svých rukách [Bély 1996: 177-178]. Vrcholu tyto pokusy dosáhly mezi lety 1760 a 1770, kdy byl nejprve v důsledku odmítnutí nových královských daní zatčen generální prokurátor parlamentu v Rennes, La Chalotais. Jeho osobní nepřítel a vrchní velitel $\mathrm{v}$ Bretani, vévoda $\mathrm{z}$ Aiguillon, se $\mathrm{v}$ provincii stal čím dál tím více nepopulárním a bretonským parlamentem a místními stavy byl obviněn ze zorganizování komplotu, a následně vypuzen ze svého úřadu [Le Roy Ladurie 1996: 433-436]. V důsledku těchto afér se roku 1771 francouzský kancléř Maupeou rozhodl zrušit všechny parlamenty v království, což vyvolalo nemalé pozdvižení, zvláště mezi šlechtou. Nově nastupující král Ludvík XVI. pod tlakem nicméně toto opatření odvolal, a bretonská šlechta tak získala pravomoci pod francouzskou nadvládou předtím nikdy nepoznané [Bély 1996: 178]. Také správa měst byla zcela předána do rukou bretonských stavů. Sám předposlední místodržitel Bretaně, Bernard de Molleville, se nad takovouto benevolencí krále pozastavuje a prohlašuje: „Tato povolení krále (...) zcela mění proces správy provincie (...) Pokud je takový králův cíl (...), nemám co říci proti, avšak zároveň již nemám v Bretani co na práci.“6

$\mathrm{S}$ touto koncentrací moci $\mathrm{v}$ rukách bretonské šlechty došlo k vážným rozepř́m mezi ní a místní buržoazií, které vyústily v přímý střet mezi oběma skupinami na zasedání bretonských stavů v prosinci roku 1788. Bretaň se v této době stává svým způsobem místem předehry Velké francouzské revoluce, kde k prolití krve dochází již v lednu roku 1789 [Bély 1996: 178]. Tato skutečnost se může na první pohled zdát paradoxní v souvislosti s pozdějším šuanským ${ }^{7}$ protirevolučním povstáním (viz dále), které mělo svůj původ právě v Bretani. Dá se ovšem pochopit v souvislosti s událostmi, které byly př́mým důsledkem revoluce. Z revoluce profitovala především bretonská buržoazie. Její členové získali většinu postů v nové administrativě po zrušení parlamentu a bretonských stavů a zmocnili se také uvolněných pozemků a majetku. I členové bývalé nobility opět odkoupili své staré majetky, a tak se většina bretonských pozemků a nemovitého majetku ocitla opět v rukách šlechtické vrstvy obyvatelstva [Cornette 2008a: 151-158]. Všeobecná nevole proti režimu nastolenému revolucí byla ke konci roku 1790 velmi citelná, a to nejen na západě Francie, ale ustavení Občanské ústavy duchovenstva situaci ještě zhoršilo, zvláště v tradičně religiózní Bretani [Furet - Ozouf 1989: 4]. Šuanskému povstání ale předcházely i jiné pokusy o protirevoluční povstání vedená bretonskou elitou a související se Srpnovými dekrety a zrušením výsad, které Bretaň jako provincie obdržela připojením k Francii v roce 1532. Stalo se tak v noci ze 4. srpna 1789, kdy byla zrušena všechna feudální privilegia, stejně tak jako privilegia provincií, měst a cechů na celém území Francie. Jedním z provokatérů byl např́íklad markýz Armand de la Rouërie, který zorganizoval opravdové spiknutí za účelem vyvolat protirevoluční povstání bretonského venkova. Jeho snahy ale neuspěly v důsledku zrady v květnu roku 1792. Nakonec zemřel o necelý rok později na horečku [Cornette 2008b: 173-175].

K propuknutí skutečných bojů v rámci šuanského povstání tedy došlo v srpnu 1792 v Mayenne a rychle se rozšiřily dále. V Bretani se do bojů zapojili hlavně obyvatelé východní části, tzv. Horní Bretaně [Furet - Ozouf 1989: 5]. Odtud dle Emmanuela Le Roy Ladurie

Citováno v [Cornette 2008a: 42].

Pojmenováno podle př́domku jednoho z vůdců lidového povstání, Jeana Chouana, vlastním jménem Jeana Cottereau. 
pochází paradox bretonského regionalismu. Nebyli to tedy západní „keltští Bretonci, kteří by se šuanského povstání účastnili, ačkoliv by s ním jejich archaičnost a tradicionalismus korelovaly. Šlechta na západě Bretaně totiž své poddané natolik vytěžovala, že mezi místním lidem neexistovala jakákoliv touha podporovat své pány v profeudálním povstání. Šuanskému povstání v Bretani tedy chyběl onen nezbytný etnický prvek daný bretonštinou, který byl pro úspěch potřebný [Le Roy Ladurie 2001: 88-89]. Šuani byli nakonec poraženi na přelomu 18. a 19. století Napoleonem [Furet - Ozouf 1989: 6]. V důsledku Francouzské revoluce tedy Bretaň zcela přišla o svůj zvláštní statut provincie a stala se z ní integrální součást francouzského státu, rozdělená na pět departmentů: Finistère, Morbihan, Côtes-du-Nord, Ille-et-Vilaine a Loire-Inférieure [Cornette 2008b: 153].

Mimo výše rozebrané aspekty (bretonský jazyk, historická nezávislost a revolty) byl dalším stavebním kamenem bretonského regionalismu především učenecký zájem o Bretaň a její odlišnou kulturu, s tradicí počínající již v 17. století. V počátku šlo opět především o bretonský „keltský“ jazyk, jenž přitahoval pozornost učenců. Právě z tohoto zájmu se nakonec zrodilo bretonské regionální sebeuvědomění u místních elit. Na následujících řádcích shrneme vývoj studia bretonského jazyka a kultury od jeho počátků až po vznik bretonského regionalistického hnutí.

Zájem učenců o keltismus značí počátek vývoje bretonského regionalismu, nicméně ten neodpovídá počátku vědeckého zájmu o Bretaň jako takovou. Slovo „Kelt“ zůstává v západní Evropě v zásadě neznámým až do konce 15. století a od počátku 16. století se debaty francouzských a německých vzdělanců omezují na starověké Kelty, které považují za své předky. Teprve až díky vědcům pocházejícím z britských ostrovů se slovo „keltský“ začíná spojovat také s Bretonci. Při studiu Zápisků o válce galské totiž zjištují, že Caesarovi neunikla shoda mezi jazyky užívanými na jihu Británie a v Gálii. Na tomto základě Edward Lhuyd (1660-1709), velšský učenec, dal jako první do souvislosti velštinu, bretonštinu, skotskou a irskou gaelštinu a tyto jazyky kvalifikoval společným př́idomkem „keltské“. Význam tohoto termínu se v průběhu 18. století proměňoval, avšak na počátku 19. století se již jeho užití ustálilo, vyjadřujíc společný jazykový charakter Bretaně, Walesu, Skotska a Irska [Chapman 1992: 201-205].

Keltská studia se vyvinula hlavně mimo „keltské“ země, avšak zabývali se jimi především vědci pocházející z těchto oblastí, jejichž rodný jazyk byl keltský. Byl jím např́klad benediktýnský mnich Louis Le Pelletier, jehož slovník Dictionnaire de la langue bretonne [Le Pelletier 1752] se v pozměněných podobách používal až do 20. století [Cornette 2008b: 604]. Na vědecké studie brzy navázalo romantické hnutí a zrodila se tzv. keltomanie. Tento fenomén byl dostartován vydáním Ossianových písní Skotem Jamesem Macphersonem v 60. letech 18. století [Haywood - Cunliffe - Stevanovitch 2002: 127-129]. Ve stejné době již působili Théophile La Tour d'Auvergne (1743-1800) a Jacques le Brigant (1720-1804), první tzv. keltomanové bretonského původu [Cadiou 2013: 247]. Věřili, že keltština byla původním prajazykem, ze kterého se vyvinuly všechny ostatní jazyky, a že se do dnešní doby zachovala právě v Bretani [Le Brigant 1787]. Nesmíme zapomínat, že v této době byla bretonština stále považována za pozůstatek staré galštiny. Teorie o osídlení Armoriky kmeny pocházejícími z jižní Británie byla všeobecně přijata až v druhé polovině 19. století [Chapman 1992: 205-206].

Nejen lingvistické studie, ale i etnologie se zrodila v druhé polovině 18 . století právě na základech keltských studií. Dílo Jacquesa Cambryho (1749-1807) pojmenované Voyage 
dans le Finistère ou état des ce département en 1794 et 1795 [Cambry 1798] („Cesta do Finistère, neboli stav tohoto departmentu v letech 1794 a 1795“) je považováno za jedno ze zakládajících děl francouzské etnologie [Cadiou 2013: 69]. Studie tohoto typu značně podporovaly nový francouzský stát v honbě za státní identitou. Již v průběhu 18 . století se objevil nový koncept vysvětlující etnicky rozdělení stavů v tehdejší Francii. Mělo se za to, že předci nejvyšších vrstev obyvatelstva byli franckého, germánského původu a že naopak třetí stav měl svůj původ v galsko-římském odkazu. Dá se tedy pochopit, že podpora keltismu a keltských studií byla pro republiku velmi výhodnou. Na jedné straně mohli republikáni ospravedlnit revoluci na etnickém základě, na straně druhé měli v rukou jednotící prvek nové republikánské společnosti [Dietler 1994: 587].

I Napoleon velmi podporoval iniciativu keltských studií a pod jeho patronátem vznikla v roce 1805 nová vědecká instituce Académie celtique („Keltská akademie“). Jacques Cambry se stal jejím prvním prezidentem a pod jeho vedením bylo hlavním cílem akademie znovuobjevit keltský jazyk a sebrat lidovou keltskou slovesnost [Cadiou 2013: 10]. Napoleon částečně ospravedlňoval svou expanzi po Evropě právě galsko-římským dědictvím, takzvaně „pouze“ obnovoval jednotu starověkých národů, protože Keltové v minulosti sídlili na podstatném území Evropy [Dietler 1994: 588]. Nakonec se Académie celtique před pádem císařství přeměnila na Société des antiquaires de France („Společnost francouzských starožitníkư“).

\section{Okolnosti vzniku a vývoj}

Pro porozumění samotného vzniku bretonského hnutí v 19. století velmi dobře poslouží citace Emmanuela Le Roy Ladurieho: „Tento regionalismus se nakonec zrodil z ran, které mu uštědřila dlouhá Francouzská revoluce (1789-1880), ničitelka provinciální autonomie. Mezi lety 1898 a 1914 jsme svědky zrodu pomíjivého, ale významného rozkvětu Unie, později Fédération régionaliste bretonne, Collège des Druides et des Bardes, asociace Bruyère bleue a také Parti national breton" [Le Roy Ladurie 2001: 91]. Jaké tedy byly tyto „rány“, které Bretaň od svého porobení ze strany francouzské vlády obdržela, a jaká byla reakce bretonské strany?

V průběhu Revoluce se ve vztahu k Bretani zrušila stará práva a privilegia vycházející z jejího zvláštního provinciálního charakteru. Snahy o vymazání regionálních specifik nicméně v období Revoluce neskončily a i následující podoby francouzské vlády se tak snažily činit nadále. První republika jako první zavedla novou politiku vůči regionálním jazykům za účelem je eliminovat, jelikož byly považovány za překážku národní jednoty státu a za federalistický a protirevoluční potenciál. Ačkoliv se tyto snahy nepodařilo První republice proměnit v realitu, tak jako se stalo u spousty ostatních „ideálů Revoluce“, začalo být v jejich důsledku používání a udržování provinciálních jazyků považováno za kontrarevoluční a antinacionální činnost [Ford 1993: 14-15].

Silný centralismus byl ve Francii velmi citelný i za Napoleona, jinak velkého podporovatele keltomanie. Využíval svých prefektů nasazených ve všech regionech francouzského státu k unifikaci, administrativní centralizaci, aniž by respektoval regionální zvyklosti a specifika. Všechen tisk se nacházel v rukách státu, a sloužil především k propagandě [Cornette 2008b: 337-338]. Další režimy francouzského státu pod restaurací Bourbonů a Červencová monarchie tyto změny správy ponechaly a nic na nich neměnily. Zachovaly 
centralismus i prefektorální systém zavedený Napoleonem [Denis 1992: 68]. Ani v nejmenším nepomýšlely na znovuobnovení vrchnostenské správy či starých provinciálních samosprávných institucí [Dupuy 2001: 33]. Císař Napoleon III. se také nezdál otevřený tomu povolit francouzským regionům otěže [Denis 1992: 72]. Represe vůči svobodnému tisku jsou toho důkazem [Cornette 2008b: 359]. Avšak i přes všechna zde pojmenovaná omezení žádný z těchto režimů, počínaje obdobím prvního císařství, ve Francii nevyžadoval jazykovou jednotu. Jednotný jazyk nebyl v této době, na rozdíl od státu, považován za nezbytnou součást jednoty národa. $V$ podání tehdejších učenců se národ nedefinoval na základech etnických či rasových, ale státních [Ford 1993: 15-16].

Naopak v období Třetí republiky až do počátku první světové války představovala jazyková jednota a další ideály Revoluce nezbytnost v udržení moci francouzského státu a jednoty národa. Již v roce 1871, ještě před ustanovením státního režimu, byly zahájeny první reorganizace území státu a bylo rozhodnuto, že centralizace bude jeho novým hlavním organizačním principem. Zároveň s tím a v reakci na neslavný konec konfliktu s Pruskem byla zavedena všeobecná branná povinnost a ustanoveno devatenáct nových těles stálé armády [Duclert 2010: 94-95]. Představitelé státu se také ve jménu jednoty národa a modernizace rozhodli investovat do vývoje infrastruktury. Přirozeným do̊sledkem takové snahy měl být ideál kulturní unifikace [Weber 1976: 195-220]. Po ustanovení republiky jako demokratického režimu byla státní propagandou zavedena skutečná republikánská doktrína a ideologie [Duclert 2010: 127-128]. Církev a náboženství byly považovány za přímé ohrožení této ideologie - „Klerikalismus? Zde je nepřítel!“ dle slavného výroku budoucího předsedy vlády, Léona Gambetty. ${ }^{8}$

Mezi lety 1879 a 1884 byla přijata řada liberálních úprav zákonodárství, mezi prvními např́iklad svoboda tisku. Avšak právo sdružovací mezi ně nepatřilo z důvodu obav z možného vlivu náboženských kongregací [Duclert 2010: 166-168]. Mimo propagandu se hlavním nástrojem implementace republikánských hodnot stává vzdělání. Jules Ferry jako nový ministr školství od roku 1879 buduje jednotný národní vzdělávací systém. Cílem bylo mimo jiné odstřihnout církev od vlivu, který měla na výchovu dětí [Fortescue 2000: 37-38]. Sjednocení vzdělávacího systému mělo také další velmi důležitý důsledek - sjednocení jazyka, a to nejen ve smyslu lingvistickém, ale také ve formě diskurzu. Dle Eugena Webera se tímto způsobem formoval sdílený symbolický jazyk, který obsahoval stejné reference a další společné body. Hranice regionů byly tímto zpơsobem překonány [Weber 1976: 333, 337]. Nicméně je potřeba si uvědomit, že v této době, před rokem 1890, se ještě ve školách respektovaly i regionální jazyky a bylo využíváno bilingvních metod výuky [Ford 1993: 19].

Přístup státu se k problematice respektování provinciálních jazyků ovšem významně proměnil $\mathrm{v}$ důsledku politických krizí režimu v posledním desetiletí 19. století. Byla to především Dreyfusova aféra, která zamíchala politickými silami a ve svém důsledku definitivně určila směr francouzské státní politiky až do dnešních dní. Pravice se v této době nadobro zdiskreditovala a katolická církev kvůli svým protidreyfusovským postojům utrpěla vážné zásahy, které vyústily až k odloučení církve od státu v prosinci roku 1905 [Fortescue 2000: 50-51]. Stejně tak postoj úřadů vůči provinciálním jazykům se vyostřil a jazyková jednota začala být považována za nezbytnost [Ford 1993: 26]. Konkrétně

8 „Le cléricalisme? Voilà l’ennemi!“ [Fortescue 2000: 33]. 
v Bretani došlo roku 1902 k zákazu vyučovat náboženství (včetně výkladu katechismu) $\mathrm{v}$ bretonštině. Toto nařízení poboư̌ilo část obyvatelstva, hlavně v Dolní Bretani, kde v této době stále většina obyvatelstva hovořila pouze bretonsky [Broudic 2006: 221].

Výše popsaná politická rozhodnutí, která měla za následek silnou centralizaci francouzského státu a ztrátu individuality periferie, rozčarovala především bretonskou inteligenci. V první polovině 19. století se také mimo jiné Bretaň stala oblíbeným motivem spisovatelů romantiků, kteř́ ji prezentovali především jako divoký, až primitivní region. Díky nim se tento obraz Bretaně rozšíril po celé Francii. Zásluhy za to nesl hlavně Honoré de Balzac, který z této představy vytvořil opravdový stereotyp. ${ }^{9}$ Bretonští intelektuálové tudíž iniciovali řadu kulturních projektů, které měly tomuto trendu a politické kulturní nivelizaci odporovat. Politicky laděné bretonské aktivity se začaly prosazovat až na konci 19. století.

$\mathrm{V}$ počátku to byli především následovníci keltomanů z Bretaně, kteří byli rozhodnuti šírit „reálný“ obraz svého kraje. Za tímto účelem byl roku 1823 založen časopis Le Lycée armoricain, jehož stránky byly věnovány hospodářským rozborům, lingvistickým studiím, dokonce publikaci středověkých textů a také pozorování zvyků a tradic bretonských venkovanů [Dupuy 2001: 33]. Na stránkách tohoto časopisu byla podle předmluvy prvního čísla „Jediná politika vynechána“ a „Pravda [byla] jejich [autorů] cílem“ [Mellinet 1823: $1,2]$.

Další skupinou, která se snažila dosáhnout velmi podobného cíle, byli bretonští folkloristé. Nejslavnějším z nich byl Théodor Hersart de la Villemarqué (1815-1895), jehož dílo pojmenované Barzaz-Breiz („Písně Bretaně“) zásadním způsobem ovlivnilo všeobecné vnímání Bretonců v pozdější době a stalo se jedním z hlavních argumentů pro zachování a obnovu soudobé bretonské kultury. Tato sbírka lidových bretonských písní s francouzským překladem byla poprvé vydána roku 1839 ve dvou svazcích o celkovém počtu šesti set čtyřiceti čtyř stran, které obsahovaly „písně historické“, „písně milostné“ a „písně náboženské", sebrané de la Villemarguém z většiny u negramotného venkovského obyvatelstva Bretaně. I přes hlasy a debatu zpochybňující její autenticitu, jež se z části potvrdily, tato sbírka významnou měrou přispěla k transferu „keltské“ reprezentace od Francie k Bretani [Guiomar 1992: 527-529]. Sběr těchto písní ovšem sloužil ještě vyššímu cíli: poukázat na vzdálené dějiny Bretaně, na vědění keltské civilizace v ní obsažené a zachované do dnešních dní, a tedy i na důležitost Bretaně v rámci Evropy [Postic - Laurent - Simon - Veillard 2003: 383]. Bretonští regionalisté konce 19. století částečně navázali na práci folkloristů, at už prímo, když používali jejich studie jako zdroj svých vlastních myšlenek, či nepř́imo, pokud využívali kulturní reprezentace Bretaně vytvořené folkloristy. ${ }^{10} \mathrm{~V}$ souvislosti s vikomtem de la Villemarqué stojí mimo jiné za zmínku i jeho aktivity jako průkopníka „interkeltských vztahü“, roku 1838 vedl bretonskou delegaci pozvanou do Walesu k účasti na bardské události, tzv. Eisteddfodu. ${ }^{11}$

9 Nejlepším př́ikladem je román Honoré de Balzaca nazvaný v českém překladu jako Šuani [Bertho 1980: $53,57]$.

10 Pro více informací o bretonském folklorismu 19. století viz Hopkin, David [2003]. Legendary places: Oral history and folk geography in nineteenth-century Brittany. In. Fowle, Frances - Thomson, Richard (ed.). Soil and Stone. Impressionism, urbanism, environment. Hants: Ashgate Publishing Limited, s. 65-84.

11 Jako Eisteddfod, v překladu „setkání, se označovala středověká velšská setkání, při kterých se soutěžilo ve zpěvu a básnictví (bardů), jejichž tradice byla roku 1700 ve Walesu obnovena [Morgan 2012: 56, 57]. 
Folkloristé sice přispěli k uznání historického významu Bretaně, ale napsat dějiny tohoto regionu bylo úkolem především tamních historiků. Aurélien de Courson (1811-1889) v tomto směru vykonal mnoho a jeho dvě díla, Essai sur l'histoire, la langue et les institutions de la Bretagne armoricaine (1840) a jeho rozšíření Histoire des origines et des institutions des peuples de la Gaule armoricaine et de la Bretagne insulaire (1843), se stala základem pro tvrzení př́buznosti obyvatel Bretaně a „keltských“ ostrovních obyvatel [Cornette 2008b: 293, 294]. Courson ve svých spisech kritizoval přílišné zaměření výzkumu na římský a řecký starověk namísto starověku galského, místního, přičemž by dle něj „výzkum starých památek v Bretani a Walesu (...) přinesl výsledky neméně důležité" [De Courson 1843: xii]. Věřil také, že by průzkum současných zvyků, obyčejů a jazyka v Bretani mohl pomoci odhalit organizaci starodávné Gálie [De Courson 1843: xi]. V jeho dílech je také citelná touha po osamostatnění Bretaně, o které mluví jako o své „vlasti“, a v souvislosti s ní zmiňuje i „svobodu dní minulých“ [De Courson 1840: xii, xiii].

Courson měl ještě jiného, slavnějšího kolegu, Arthura le Moyne de la Borderie (1827-1901), kterému se přezdívá „Bretonský Lavisse“. ${ }^{12}$ Po ukončení studií na École de Chartes v roce 1852 se stává historikem a aktivistou autonomních snah Bretaně. Z jeho děl později významnou měrou čerpali právě bretonští regionalisté [Cadiou 2013: 235; Cornette 2008b: 295]. Byl ve své době jedním z prvních vědců, kteří veřejně prohlašovali, že „skutečný původ armorického bretonského národa se nalézá v dlouhodobé emigraci ostrovních Bretonců, kteří (...) právě v Armorice hledali svou novou vlast“ [De la Borderie 1883: 2]. Dokonce tvrdil, že Bretaň je „skutečným národem, (...) dokonale svébytným ve svých základech“.13 Jeho největším prrínosem bylo monumentální dílo, šestisvazková Histoire de la Bretagne, vydaná mezi lety 1899 a 1906.

V polovině 19. století, konkrétně roku 1843, tyto bretonské kulturní iniciativy získali institucionální podobu v založení Association bretonne. Původně se jednalo o organizaci, jež se v prvé řadě věnovala bretonskému zemědělství a hospodářské problematice. K dosažení jejich cíle, tedy zlepšení hospodářské situace Bretaně, jim měl pomoci jejich nový časopis, protože soudili, že „bretonský kraj (...) má své zvláštní potřeby, o kterých muži řídící chod společnosti vědí často jen málo" ${ }^{14}$ Avšak brzy byla v rámci asociace, především pod vlivem de la Villemarquého, vytvořena nová archeologická sekce. Stojí za zmínku, že ve stejné době začaly vznikat po celém regionu typově stejné archeologické departementální společnosti [Dietler 1994: 595]. V důsledku založení této nové sekce se Association bretonne stala hlavním šiřitelem bretonských emancipačních myšlenek. Její časopis Bulletin archéologique na svých stránkách šířil informace především o dějinách a bretonském umění „od galské až po moderní dobu“ [Bulletin archéologique 1849: vii]. Většina výše jmenovaných osobností v tomto časopise publikovala a jinak se podílela na aktivitách společnosti (například Courson byl jejím viceprezidentem a Borderie tajemníkem). Z tohoto důvodu začala být asociace brzy podezřívána ze sdružování legitimistů (hnutí usilující o obnovení monarchie a dosazení legitimního panovníka) [Postic - Laurent - Simon - Veillard 2003: 384]. Francouzský stát tento vývoj s obavami sledoval. Napoléon III. se rozhodl zakročit a v roce 1859 činnost celé asociace zakázal [Fouéré 1977: 18].

12 Pod vedením Ernesta Lavisse (1842-1922) vyšla na přelomu 19. a 20. století sedmnáctisvazková Histoire de France a on sám je považován za otce francouzské národní historie.

13 Citováno v [Cadiou 2013: 235].

14 Citováno v [Cornette 2008b: 245]. 
Mimo výše zmíněný Bulletin archéologique existovaly i další časopisy, které šírily informace o tzv. bretonských zájmech. Byly jím např́iklad známý Revue de Bretagne et de Vendée, založený roku 1857 de la Borderiem jako „sbírka literárních, historických a vědeckých článků, sloužící křestanským a sociálním myšlenkám, věnující se zvláště Západu Francie“ [Revue 1857: předmluva]. Jako př́klad bretonsky psaného časopisu lze uvést Feiz ha Breiz, neboli „Víra a Bretaň", který byl, jak už název napovídá, katolickým a tradicionalistickým týdeníkem. Byl založen biskupstvím v Quimper (Dolní Bretaň) roku 1865 a stal se v průběhu století časopisem zastávajícím silně separatistické postoje [Cadiou 2013: 146]. Tyto časopisy (a jiné další) nabízely významný prostor pro diskuzi, šíření a sdílení informací o „jedinečném“ charakteru Bretaně. Hrály významnou roli v rozšíření regionálních pocitů sounáležitosti mezi gramotnou sociální vrstvou obyvatelstva.

I v druhé polovině 19. století se Hersart de la Villemarqué snažil udržovat „interkeltskéc vztahy. Po velšském vzoru založil bretonskou bardskou akademii a ve spolupráci s ostatními keltskými nadšenci roku 1867 zorganizovali druhý mezinárodní keltský kongres v Saint-Brieuc v Bretani, svého druhu bretonský Eisteddfod. Měli tak v plánu učinit už roku 1859, ale vzhledem ke zrušení Association bretonne byl tento literární a hudební svátek odložen [Postic - Laurent - Simon - Veillard 2003: 384]. Pro bretonské učence tato událost představovala počátek očekávaných intenzivních interkeltských vztahů, které vnímali jako významný nástroj pro přímou obranu bretonské kultury vůči národní francouzské. Nicméně francouzsko-pruská válka a nastolení republiky zabránilo dalšímu vývoji tohoto projektu [Chartier 2010: 171, 182].

$\mathrm{Na}$ předešlých stránkách byly nastíněny prríčiny vzniku bretonského regionalistického hnutí a rovněž došlo k načrtnutí vývoje po Francouzské revoluci, jenž předcházel samotnému vzniku bretonského regionalismu. Za ten je považováno založení Union régionaliste bretonne (URB) roku 1898. Někteří autoři založení této organizaci považují za počátek bretonského hnutí jako takového [Cornette 2008b: 295], jelikož URB představovala jednu z prvních iniciativ, která požadovala autonomii Bretaně nejen v oblasti kulturní, ale také administrativní a ekonomické [Denis 1992: 79]. Období mezi založením URB a rokem 1914 navíc uzavírá určitý typ regionalistického diskurzu, který by se dal nazvat v souvislosti s pozdějším vývojem jako konzervativní - počínaje sjednocením regionalistických aktivit Bretonců v jedné organizaci a konče diverzifikací těchto iniciativ v důsledku války. V této části studie bude podrobněji rozebrána URB (a její aktivity) jako hlavní reprezentant bretonského regionalismu v období před první světovou válkou.

Tak jako ostatní regionalistická hnutí ve Francii, i ten bretonský byl vystavěn na základech předešlého kulturního, hlavně literárního hnutí. URB se začala formovat již v 90. letech 19. století a byla nakonec založena v srpnu roku 1898 ve městě Morlaix (Dolní Bretaň), kde se „v konferenční místnosti Hôtel-de-Ville (radnice) sešli vážené a slavné osobnosti bretonského literárního světa“ [Bulletin 1902: 9]. Hlavním cílem této organizace, proklamovaným v prvním čísle jejich bulletinu, měla být podpora a obrana zájmů regionálních, politických (poprvé explicitně uvedeno), literárních, zemědělských či obchodních, stejně tak jako vytvoření „bariéry proti pařížské invazi, a silné základny k podpoření administrativní decentralizace a relativní autonomie provincii“" [Bulletin 1902: 12]. Členové URB k naplnění této role obránce bretonských zájmů ustanovili postupně čtyři hlavní sekce, $\mathrm{z}$ nichž každou vedl volený prezident. Jednalo se o: 1 . Hospodářskou a vědeckou sekci; 2. Sekci historickou a literární; 3. Sekci bretonského jazyka a literatury; 4. Sekci 
výtvarného umění [Bulletin 1903: 7]. Je nicméně potřeba připomenout, že URB nepožadovala úplnou nezávislost Bretaně, faktickou samostatnost, ale pouze autonomii založenou na regionálních principech $\mathrm{v}$ rámci Francie. Věrili, že pouze pomocí decentralizace mohou „dosáhnout morální autonomie, složené z naprostého respektování [jejich] tradic a svobod“, na něž údajně měli, „nepopiratelné právo“ [Bulletin 1905: 38].

Počet členů Unie dosahoval několika stovek (přibližně 700 nejvíce). Mezi nejznámější z nich patřili Anatole Le Braz, její první prezident, na této pozici nahrazen roku 1903 markýzem l'Estourbeillonem, hlavním představitele URB, který si tento post udržel až do roku 1946. Dalšími důležitými postavami byli zpěvák Théodore Botrel, Jean Choleau v čele hospodářské sekce, dále Taldir Jaffrennou, Francis Even a François Vallée, kteří byli hlavními podněcovateli bretonského Gorseddu (neodruidské a neobardské organizace), a nakonec Charles Le Goffic, známý literát, a mnoho dalších. Hlavní událostí v životě členů URB byl každoroční kongres, který se pokaždé konal v jiném bretonském městě. Od roku 1907 byla zavedena další pravidelně konaná akce, a to Assises d'hiver či Assises de printemps, tedy „Zimní, resp. „Jarní zasedání. Na základě každého z kongresů a zasedání byl vydán bulletin, který obsahoval zápis $\mathrm{z}$ celého průběhu a také většinu $\mathrm{z}$ př́spěvků pronesených členy URB na dané události. Tyto bulletiny představují hlavní zdroj informací o aktivitách Union régionaliste bretonne, jež zde budou nyní ve stručnosti popsány.

Aktivity regionalistů byly přirozeně inspirovány ostatními hnutími „malých národü“ té doby a jejich snahami o obrození kolektivní identity. Patřila mezi ně především obrana a ochrana místního, často minoritního jazyka, a v prípadě bretonského regionalistického hnutí tomu nebylo jinak. Jazyk byl významným argumentem, na kterém bylo bretonského hnutí založeno, a dodával smysl a význam jejich činnosti, tak jako u ostatních, zvláště národních hnutí [Thiesse 1999: 70]. Regionalisté sami přiznávají životní důležitost bretonštiny při jejich aktivitách a považují ji za „zbraň prvního řádu“, jež mají ve svých rukách, tak jako u „úspěšných hnutí Finů, Čechů a obyvatel Provence“ [Bulletin 1908: 106]. Nicméně v prŕípadě Bretaně byla situace komplikována tím, že se bretonsky tradičně hovořilo pouze v západní Dolní Bretani a na celé půlce území tomu tak nebylo pravděpodobně nikdy. Tuto nesourodost se bretonští regionalisté snažili překonat tím, že dávali dưraz na bilingvismus, přičemž racionálně argumentovali jeho všeobecnou výhodností, protože „člověk, který zná dva jazyky, stojí za čtyři“ [Bulletin 1909: 56].

Bretonské regionalistické hnutí si dle „klasického“ modelu národních hnutí mimo jiné také vypůjčilo znovuobjevení a propagaci původní a originální lidové kultury. Jednalo se především o „národní kroj“, hudbu a bretonské lidové divadlo. Regionalisté byli u všech Bretonců přesvědčeni o „hluboce zakořeněném citu pro umění“ [Bulletin 1906: 146]. Cílem bylo jednak kulturně Bretaň co nejvíce odlišit od Francie, jednak přitáhnout běžné obyvatelstvo $\mathrm{k}$ regionalistickému hnutí. Mělo jít také o prostředek, jak zabránit emigraci Bretonců pryč $\mathrm{z}$ regionu, která byla $\mathrm{v}$ této době poměrně masovou záležitostí, a také řešení sociálních problémů. Věřili, že „bez vlastního jazyka, bez čepců ${ }^{15}$ se bretonské dívky na venkově budou nudit" [Bulletin 1908: 138], a že lidové divadlo představuje „nejúčinnější zbraň proti pálence a kabaretu“ [Bulletin 1907: 107].

15 Tzv. Coiffe bretonne nebo Coiffe bigoudène je dodnes prezentován jako tradiční ženský čepec, který je součástí bretonského kroje. 
V otázce etnicity se regionalisté opírali také o bretonský jazyk, který byl př́buzný s velštinou a dalšími jazyky z britských ostrovů. Prezentovali tedy obyvatele Bretaně v otázce původu jako Kelty. Pro regionalisty, kteří požadovali autonomii Bretaně, bylo nadmíru výhodné používání etnické diferenciace jejího obyvatelstva od zbytku Francie. Z tohoto důvodu také akcentovali „interkeltské“ vztahy, jak je sami nazývali, tedy úzkou spolupráci se členy ostatních „keltských národư“. V této oblasti členové URB navázali na Hersarta de la Villemarqué, účastnili se pankeltských kongresů na britských ostrovech, a dokonce je i sami v Bretani pořádali. Obzvláště s Velšany udržovali speciální vztahy. Po vzoru velšského Gorseddu, tedy místní neodruidské a neobardské organizace, byl založen Gorsedd bretonský a členové obou organizací se pravidelně stýkali, mimo jiné také na každoročních kongresech URB. ${ }^{16} \mathrm{~V}$ následných bulletinech poté nechybí detailní popisy bardských ceremonií. ${ }^{17}$

Nesmíme ovšem zapomínat na to, že Union régionaliste bretonne byla představitelkou regionalistického hnutí, nikoliv nacionálního, ačkoliv byla nejednou obviňována ze separatismu. URB se tedy snažila dokazovat svoji loajalitu francouzskému státu, přičemž dokonce Bretaň vzhledem k jejím obětem (zvláště vojenským) prezentují jako „nejvíce loajální francouzskou provincii“ [Bulletin 1903: 32]. Na druhou stranu jsou v bulletinech URB velice často slova „národ“ a „národni“ spojována s Bretaní, současně ale i s Francií (i když v menší míře). V souvislosti s tímto jevem a výše zmíněnými podobnostmi mezi bretonským hnutím a hnutím ostatních evropských malých národů té doby jsme v případě URB tedy svědky podivné dichotomie v kvalifikace jejich hnutí jako regionalistického či nacionálního. Jak zmiňuje i Miroslav Hroch, neúspěch bretonského hnutí této doby mohl mimo jiné tkvět $\mathrm{v}$ jeho nejasné definici a následnému zmatení potenciálních přivrženců [Hroch 1999: 49].

Neúspěch bretonského regionalistického hnutí v období před první světovou válkou byl důsledkem množiny příčin (nepříznivá hospodářská situace, obecný sociokulturní kontext doby, aj). Nicméně je v této souvislosti potřeba zmínit nesoulad názorů mezi samotnými členy Union a její rozdělení. Roku 1911 se skupina členů rozhodla od URB odštěpit a založili vlastní organizaci nazvanou Fédération régionaliste de la Bretagne (FRB). Dle prvního čísla bulletinu nové FRB se tak stalo v důsledku tří hlavních př́ičin: „zavedení cizích velkosvětských elementů“, autoritářství prezidenta de l'Estourbeillona a „nový okruh lidí“ kolem něj, kteří chápou regionalismus jen jako své „obveselení“ [Bulletin 1912: 3]. Taldir Jaffreannou tuto roztržku také komentoval v jednom ze svých článků, z něhož vyplývá, že byla vedena na dělící linii mezi markýzem de l'Estourbeillonem, aristokracií, Bretonci z Paříže či Horní Bretaně na straně jedné (URB) a celtisans, Bretonců z Dolní Bretaně, bardů a nižšího kléru na straně druhé (FRB) [Jaffrennou 1912: 191]. Zdá se, že neodruidské a neobardské aktivity mohly být také jednou z prŕíčin sporu mezi URB a FRB.

\section{Závěr}

První světová válka aktivitu obou regionalistických organizaci značně utlumila a ani po jejím skončení se již regionalismu nedostalo takové pozornosti. Diskurz doby se vlivem

16 Pro více informací o bretonském neodruidismu a neobardismu viz Le Stum, Philippe [1998]. Le néo-druidisme en Bretagne: origine, naissance et développement, 1890-1914. Rennes: Éd. „Ouest-France“.

17 Např. popis cérémonie du glaive v [Bulletin 1905: 155]. 
válečných útrap zcela proměnil a bretonské hnutí se značně diverzifikovalo. $V$ poválečném období sledujeme zrod nového bretonského hnutí, jež by se dalo kvalifikovat jako požadující úplnou samostatnost, tedy dokonce až jako nacionální. Tento tzv. druhý Emsav je institucionálně reprezentován hlavně časopisem Breiz Atao. ${ }^{18}$ URB nadále existovala, avšak spíše už jen skomírala. Markýz de l'Estourbeillon zastával pozici prezidenta URB až do své smrti, roku 1946, a o rok později je URB rozpuštěno v Association bretonne [Cadiou 2013: 418]. FRB se v poválečné době snažila řešit hlavně hospodářské otázky Bretaně, ale i ona po roce 1923 ztrácí na významu a je ve svých zájmech postupně nahrazena jinými subjekty [Cadiou 2013: 144]. Tímto neslavným způsobem tedy skončil původní bretonský regionalismus předválečné éry.

Cílem této studie bylo poukázat na dávné i nedávné prŕčciny vzniku bretonského regionalistického hnutí, uvést okolnosti jeho vzniku a vývoje do roku 1914 a dále jej také ve stručnosti charakterizovat. $V$ první části jsme se zaměřili na tři hlavní aspekty dějin Bretaně, které zásadním zpo̊sobem ovlivnily vznik bretonského hnutí a které také patřily mezi jeho hlavní argumenty: existence bretonského jazyka, historická nezávislost území Bretaně a revolty proti francouzské nadvládě jako zdroj inspirace pro bretonské regionalisty. $V$ závěru této části jsme ještě poukázali na aspekt učeneckého zájmu o Bretaň, $\mathrm{v}$ jehož produkci byly vytvořeny základní vědecké texty, o něž se regionalisté opírali. $Z$ této vlny zájmu také vzešli první předchůdci místního regionalismu. Následující část studie byla věnována okolnostem vzniku regionalismu a byla časově zaměřena na 19 . století. $V$ úvodu byl popsán politický vývoj francouzského státu $\mathrm{v}$ tomto období a jeho význam pro proměny statusu Bretaně v rámci něj. Ty měly totiž velký vliv na vznik regionalismu (nejen bretonského). Poté jsme si představily první iniciativy tohoto typu, zároveň př́mé předchůdce bretonských regionalistů. Vrchol studie byl věnován Union régionaliste bretonne, první regionalistické bretonské organizaci, založené roku 1898, a její charakteristice. Jak již bylo uvedeno výše, tento text slouží především jako úvod pro zájemce nejen o bretonské hnutí, ale o hnutí regionalistického typu obecně. Předložený text vytvořil potřebný prostor pro kontextualizaci této problematiky, jakož i pro dalš́i badatele v oblasti regionalistických a nacionálních hnutích.

\section{Prameny}

Bulletin archéologique de l'Association bretonne (1). [1849]. Rennes. Dostupné z: <http://gallica.bnf.fr /ark:/12148/bpt6k2074644> [16. 4. 2017].

Bulletin de la Fédération régionaliste de la Bretagne. [1912]. Keraez.

Bulletin de l'Union régionaliste bretonne. Congrès de Morlaix.-Vannes.-Guingamp.-Quimperlé de 1898 à 1901. [1902]. Saint Brieuc.

Bulletin de l'Union régionaliste bretonne. Congrès d'Auray de 1902. [1903]. Saint-Brieuc.

Bulletin de l'Union régionaliste bretonne. Congrès de Gourin 1904. [1905]. Redon.

Bulletin de l'Union régionaliste bretonne. Congrès de Questembert et de Rostrenen 1907. [1908]. Redon.

Bulletin de l'Union régionaliste bretonne. Congrès de Plougastel-Daoulas 1908. [1909]. Redon.

18 Breiz Atao („Bretaň navždy“) byl název časopisu, který vycházel mezi lety 1919 a 1939 a ve svém rozšířeném významu toto slovní spojení představuje celek bretonského hnutí v meziválečném období [Cadiou 2013: 50; Cornette 2008b: 453]. Pro více informací o Breiz Atao viz Carney, Sébastien (ed.) [2015]. Breiz atao!: Mordrel, Delaporte, Lainé, Fouéré: une mystique nationale, 1901-1948. Rennes: Presses universitaires de Rennes. 
Bulletin de l'Union régionaliste bretonne. Congrès de Saint-Pol-de-Léon 1905. [1906]. Redon.

Bulletin de l'Union régionaliste bretonne. Congrès de Carnac 1906. [1907]. Redon.

Cambry, Jacques [1798]. Voyage dans le Finistère, ou État de ce département en 1794 et 1795. T. 1. Paris. Dostupné z: <http://gallica.bnf.fr/ark:/12148/bpt6k103387b> [16. 4. 2017].

De Courson, Aurélien [1843]. Histoire des origines et des institutions des peuples de la Gaule armoricaine et de la Bretagne insulaire: depuis les temps les plus reculés jusqu'au Ve siècle. Saint-Brieuc. Dostupné z: $<$ http://gallica.bnf.fr/ark:/12148/bpt6k39887v> [16. 4. 2017].

De Courson, Aurélien [1840]. Essai sur l'histoire, la langue et les institutions de la Bretagne armoricaine. Paris. Dostupné z: <www.archive.org> [cit. 16. 4. 2017].

De la Borderie, Arthur le Moyne [1883]. Du rôle historique des saints de Bretagne dans l'établissement de la nation bretonne armoricaine. Rennes. Dostupné z: <http://gallica.bnf.fr/ark:/12148/bpt6k57664811> [16. 4. 2017].

Jaffrennou, François [1912]. La genèse d'un mouvement: articles, doctrines et discours 1898-1911. Carhaix: Impr. du „Peuple“.

Larousse, Pierre [1875]. Grand dictionnaire universel du XIXe siècle: français, historique, géographique, mythologique, bibliographique..., T. 13 POUR-R. Paris [online]. Dostupné z: <http://gallica.bnf.fr /ark:/12148/bpt6k205365n> [15. 4. 2017].

Le Brigant, Jacques [1787]. Observations fondamentales sur les langues anciennes et modernes, ou Prospectus de louvrage intitulé: la Langue primitive conservé. Paris. Dostupné $\mathrm{z}:<\mathrm{http}: / / g a l l i c a . b n f . f r / a r k: / 12148$ /btv1b86268793> [16. 4. 2017].

Le Pelletier, Louis [1752]. Dictionnaire de la langue bretonne, où l’on voit son antiquité, son affinité avec les anciennes langues, l'explication de plusieurs passages de l'Écriture Sainte, et des auteurs profanes, avec l'étymologie de plusieurs mots des autres langues. Paris. Dostupné z: <http://gallica.bnf.fr/ark:/12148 /bpt6k10403699> [16. 4. 2017].

Mellinet, Camille (ed.) [1823]. Le Lycée armoricain 1 (1). Dostupné z: <http://gallica.bnf.fr/ark:/12148 /bpt6k1100284> [16. 4. 2017].

Revue de Bretagne et de Vendée (Vannes) (1). [1857]. Nantes. Dostupné z: <http://gallica.bnf.fr/ark:/12148 /bpt6k110244x> [16. 4. 2017].

\section{Literatura}

Bély, Lucien (ed.) [1996]. Dictionnaire de l'Ancien Régime. Paris: PUF.

Bertho, Catherine [1980]. Linvention de la Bretagne. Genèse sociale d'un stéréotype. Actes de la recherche en sciences sociales 35 (1): 45-62.

Broudic, Fañch [1995]. La pratique du breton de l'Ancien Régime à nos jous. Rennes: Presses universitaires de Rennes.

Broudic, Fañch [2006]. Linterdiction du breton en 1902: une étape vers la Séparation. In. Balcou, Jean (ed.). Les Bretons et la Séparation, 1795-2005. Rennes: Presses universitaires de Rennes.

Cadiou, Georges [2013]. Emsav. Dictionnaire critique, historique et biographique. Spézet: Coop Breizh.

Cornette, Joël [2008a]. Histoire de la Bretagne et des Bretons, Tome 1. Paris: Éd. du Seuil.

Cornette, Joël [2008b]. Histoire de la Bretagne et des Bretons, Tome 2. Paris: Éd. du Seuil.

Croix, Alain - Cassard, Jean-Christophe - Le Quéau, Jean-René (ed.) [2008]. Dictionnaire d'histoire de Bretagne. Morlaix: Skol Vreizh.

Denis, André Yann [1992]. Histoire du mouvement breton. Paris: Pensée universelle.

Dietler, Michael [1994]. „Our Ancestors the Gauls“: Archaeology, Ethnic Nationalism, and the Manipulation of Celtic Identity in Modern Europe. American Anthropologist, New Series 96 (3): 584-605.

Duclert, Vincent - Cornette, Joël (ed.) [2010]. La république imaginée, 1870-1914. Paris: Belin.

Dupuy, Roger [2001]. Elites et identité bretonne de l'Ancien Régime à la Monarchie de Juillet. In. Nicolas, Gilbert (ed.). La Construction de l'identité régionale. Les exemples de la Saxe et de la Bretagne du XVIII au XXe siècle. Rennes: Presses universitaires de Rennes.

Flory, Thiébaut [1966]. Le mouvement régionaliste français: sources et développements. Paris: PUF. 
Ford, Caroline C. [1993]. Creating the nation in provincial France: religion and political identity in Brittany. New York: Princeton University Press.

Fortescue, William [2000]. The Third Republic in France, 1870-1940. London: Routledge.

Fouéré, Yann [1977]. Histoire résumée du mouvement breton: du XIXe siècle à nos jours, 1800-1976. Quimper: Éditions Nature et Bretagne.

Furet, François - Ozouf, Mona (ed.) [1989]. A critical dictionary of the French Revolution. Cambridge: Belknap Press of Harvard University Press.

Guiomar, Jean-Yves [1992]. Le Barzaz-Breiz de Théodore Hersart de la Villemarqué. In. Pierre, Nora (ed.). Les lieux de mémoire. III. Les France 2. Traditions. Paris: Gallimard.

Haywood, John - Cunliffe, Barry - Stevanovitch, Colette [2002]. Atlas historique des Celtes. Paris: Autrement.

Hroch, Miroslav [1999]. V národním zájmu. Praha: Nakladatelství Lidové noviny.

Chapman, Malcolm [1992]. The Celts: The Construction of a Myth. London: St Martin's Press.

Chartier, Erwan [2010]. La construction de linterceltisme en Bretagne, des origines à nos jours: mise en persective historique et idéologique. Dizertační práce. Rennes: Université Rennes 2.

Le Roy Ladurie, Emmanuel [1996]. The Ancien Régime. Oxford: Blackwell Publishers.

Le Roy Ladurie, Emmanuel [2001]. Histoire de France des régions. La périphérie française, des origines à nos jours. Paris: Éd. du Seuil.

Markale, Jean [1985]. Identité de Bretagne. Paris: Editions Entente.

Morgan, Prys [2012]. From a Death to a View: The Hunt for the Welsh Past in the Romantic Period. In. Hobsbawm, Eric - Ranger, Terence (ed.). The Invention of Tradition. Cambridge: Cambridge University Press.

Postic, Fañch Laurent, Donatien - Simon, Jean-François - Veillard, Jean-Yves [2003]. Reconnaissance d'une culture régionale: la Bretagne depuis la Révolution. Ethnologie française 33 (3): 381-389.

Thiesse, Anne-Marie [1992]. Linvention du régionalisme à la Belle Epoque. Le Mouvement social. 1992 (3): 11-32.

Thiesse, Anne-Marie [1999]. La création des identités nationales : Europe XVIII $-X X{ }^{e}$ siècle. Paris: Le Grand livre du mois.

Weber, Eugen [1976]. Peasants into Frenchmen: the Modernization of Rural France, 1870-1914. Stanford: Stanford University Press.

Williams, Raymond [1983]. Keywords. A Vocabulary of Culture and Society. New York: Oxford University Press.

Martina Reiterová je absolventkou evropského magisterského programu TEMA, v jehož rámci studovala na Eötvös Loránd University v Budapešti a na École des hautes études en sciences sociales v Pařízi. Počínaje rokem 2017 pưsobí jako doktorandka na Ústavu světových dèjin na Filozofické fakultě Univerzity Karlovy, v Semináři obecných a komparativních dějin. Ve svém výzkumu se zaměřje na regionální a národní hnutí tzv. keltských zemí (Irsko, Skotsko, Wales a Bretaň) na přelomu 19. a 20. století. 